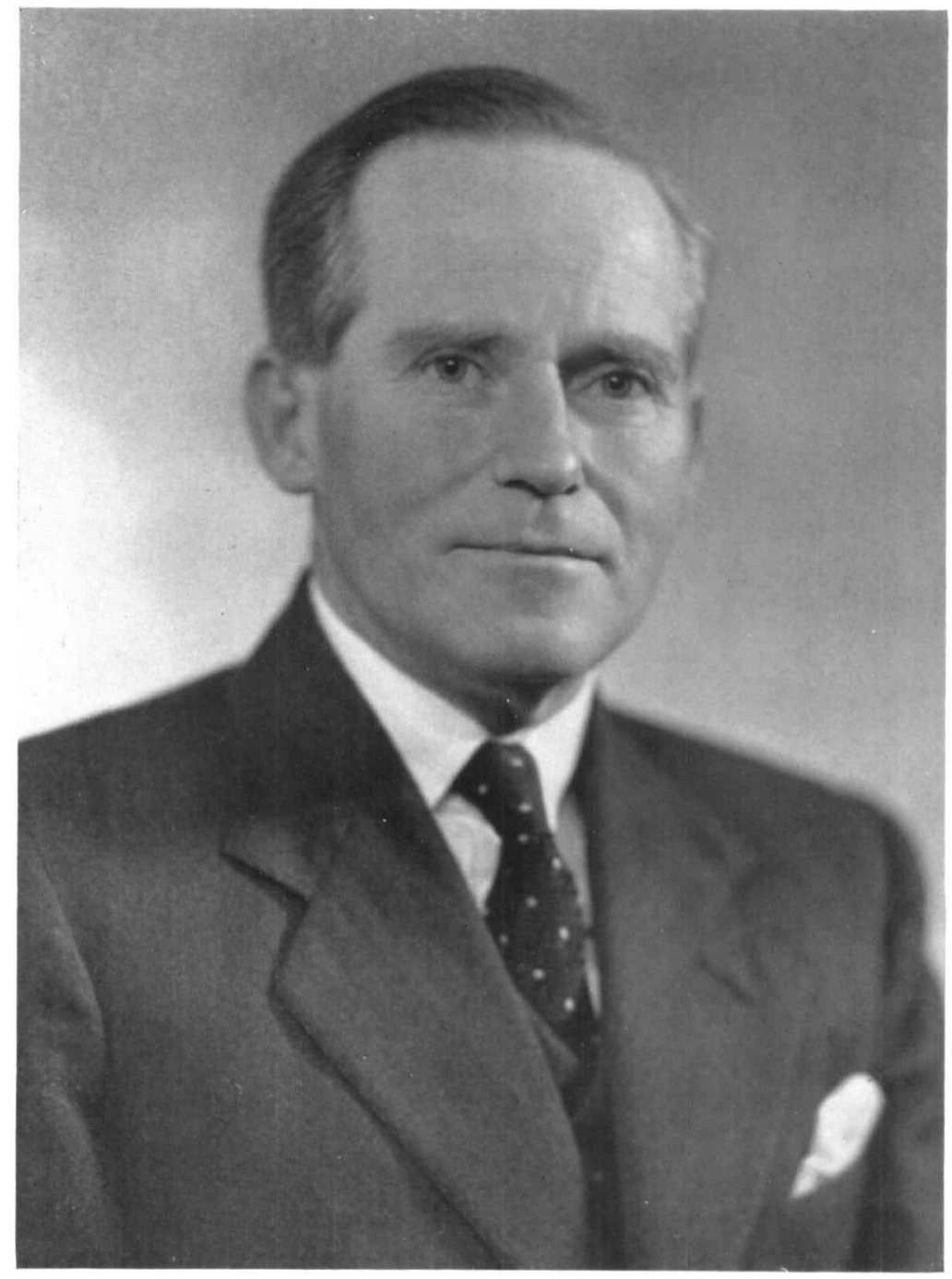

PROFESSOR WILLIAM RIDDET, C.B.E. 


\section{PROFESSOR WILLIAM RIDDET}

Readers will have heard with much regret of the death on 30 December 1958 of Professor William Riddet at the age of 62 .

Riddet was born, and remained, a Scot with all of those excellent attributes we expect in the best of his countrymen. He was associated with the Journal of Dairy Research from the start, his name appearing on Volume 1, Number 1, November 1929, as overseas correspondent in New Zealand.

His student career at the West of Scotland College of Agriculture and Glasgow University was brilliant. After a short period as lecturer at the West of Scotland College he accepted in 1925 the newly created Professorship of Agriculture at Auckland University College, New Zealand. Before leaving England he spent some time here at the National Institute for Research in Dairying, making contacts which were never broken. I well remember the impression he made on me. Although he seemed very young for a Professorship I was in no doubt as to his capacity. Having quickly impressed the authorities with his success, in collaboration with Sir Geoffrey Peren, in the herculean task of founding the Massey Agricultural College which also accommodated the Dairy Research Institute (New Zealand Department of Scientific and Industrial Research), he became almost as of right Professor of Dairying at the College and Director of the Institute. Between the N.I.R.D. and the N.Z. Research Institute there has always been a strong, indeed a brotherly, bond. Witness only the fact that one of Riddet's last imaginative pieces of work was the dispatch to our Bacteriology department of a team of workers, as much for the mutual picking of brains as for the search for a solution of a particular problem. Riddet had long wished for this kind of exchange of workers and he lived to see its achievement.

He quickly showed that he was a first-class administrator and maintained his capacity to the very last. When I saw him some three years ago, he had already fallen a victim to the leukaemia which in the end proved fatal. He was under no delusions about his condition, but he was looking and planning ahead as he always did.

It was Sir Ben Lockspeiser who said: 'Let me therefore conclude by underlining the importance of good administration, but by reminding you also that administration in science will not, of itself, produce a single new idea and without new ideas science would cease to exist.' There was no question of lack of new ideas with Riddet. He was most exuberant-so much so that without the enthusiastic co-operation of his colleagues he could never have brought a fraction of his plans to fruition. But to fruition many of them came and the excellence of the work of his Institute, at the hands of Dr. Whitehead and Dr McDowall, to mention only two, is universally acknowledged and acclaimed.

He was as thorough as a teacher as he was as an administrator. But he also endeared himself to his friends by his enthusiasm in the smaller things-for example, as a trustee of St Peter's School, Cambridge, N.Z., he made a hobby of managing their dairy farm for many years.

His reputation being made, he was widely honoured, and in 1954 was created a C.B.E. The memory of his life and works will endure.

A. T. R. MATTICK

National Institute for Research in Dairying, Shinfield, Reading 